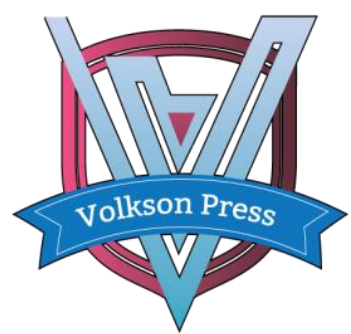

\title{
RESEARCH ON THE PRESENT SITUATION AND PROBLEMS OF PERFORMANCE EVALUATION SYSTEM IN SIHONG RURAL COMMERCIAL BANK
}

\author{
Liu He*, Bi Ke \\ School of Economics and Management, Jiangsu University of Science and Technology, Zhenjiang, P.R. China. \\ *Corresponding Author email: 1203324194@qq.com
}

This is an open access article distributed under the Creative Commons Attribution License, which permits unrestricted use, distribution, and reproduction in any medium, provided the original work is properly cited.

\section{ARTICLE DETAILS}

Article History:

Received 26 June 2018

Accepted 2 July 2018

Available online 1 August 2018

\begin{abstract}
Traditional system of performance evaluation of enterprise already couldn't satisfy the needs of the strategic management of contemporary society, which makes the enterprise have to undergo a profound change. The performance evaluation system of enterprise provides timely and effective self-assessment system to guide and supervise the normal operation of enterprises. The stand or fall of its design directly has effect on the survival and development of the corporation. Therefore, the system is going on a major change. Modern performance evaluation is mainly composed of EVA system and BSC system. The biggest advantages of EVA consider the equity capital cost, and it is more real and effective for the evaluation of business performance. BSC is based on the enterprise strategy and analyzes the factors that affect enterprise value, which contribute to the enterprise management decision of making rationalization. This article finds the system problems in practical application and provides countermeasures through research and analysis of the system at present, which is beneficial to make it more reasonable that the system of performance evaluation of the commercial bank.
\end{abstract}

KEYWORDS

Performance appraisal, EVA, Strategic Management, Bank of Commerce.

\section{INTRODUCTION}

The process of performance evaluation of commercial Banks in China is as follows: Performance evaluation originated in the late 16th century. With the emergence of the company system and the separation of ownership rights, the development of management theory improves the performance evaluation [1]. In the early stage of capitalist industrialization, performance evaluation was mainly cost index. In the late 1980s, performance evaluations were converted to financial indicators by cost indicators. In the late 1990s, the performance evaluation was based on financial indicators and targeted at maximization of enterprise value. In the 21st century, performance evaluation is transformed from financial indicators into financial and non-financial indicators [2].

\section{THE CURRENT SITUATION OF SIHONG COMMERCIAL BANK} PERFORMANCE EVALUATION SYSTEM

2.1 The performance evaluates of subordinate branch in the bank

Table 1: The performance appraisal index of the bank's president

\begin{tabular}{|l|l|l|l|}
\hline \multirow{5}{*}{ classification } & Index & computational formula & weight \\
\hline \multirow{3}{*}{$\begin{array}{l}\text { Benefit } \\
\text { management } \\
\text { category }\end{array}$} & ROA & Profit after adjusting risk/general assets & 60 \\
\cline { 2 - 5 } & The per capita economic returns. & Profit after adjusting risk/number of staff and workers & 130 \\
\cline { 2 - 5 } & $\begin{array}{l}\text { Seturn on capital } \\
\text { Sustainable } \\
\text { development class }\end{array}$ & $\begin{array}{l}\text { Profit after adjusting risk/Simulated economic capital } \\
\text { occupancy }\end{array}$ & 80 \\
\cline { 2 - 5 } & Cost income ratio & cost in business/net operating profit & 120 \\
\cline { 2 - 4 } & Per capita deposit spread income & Deposit spread income/number of staff and workers & 20 \\
\hline
\end{tabular}




\begin{tabular}{|c|c|c|c|}
\hline & $\begin{array}{l}\text { Average interest rate growth of loan } \\
\text { interest }\end{array}$ & & 35 \\
\hline & The per capita loan interest paid & Interest paid on loan/number of staff and workers & 35 \\
\hline & $\begin{array}{l}\text { Intermediate business income per } \\
\text { capita }\end{array}$ & $\begin{array}{l}\text { Net income of intermediate business/number of staff and } \\
\text { workers }\end{array}$ & 40 \\
\hline & $\begin{array}{l}\text { Proportion of revenue from } \\
\text { intermediary business }\end{array}$ & Net income of intermediate business/net revenue & 24 \\
\hline & Personal assets revenue ratio & Personal assets business income/interest revenue & 24 \\
\hline & $\begin{array}{l}\text { In the proportion of high-end } \\
\text { customers }\end{array}$ & $\begin{array}{l}\text { The number of individuals in the high-end } \\
\text { customers/Total number of individual effective } \\
\text { customers }\end{array}$ & 24 \\
\hline & $\begin{array}{l}\text { Corporate high quality customer loans } \\
\text { accounted for }\end{array}$ & $\begin{array}{l}\text { Corporate high quality customer loan balance/All } \\
\text { corporate client loans }\end{array}$ & 24 \\
\hline & Proportion of non interest assets & Non-interest-bearing assets balance/total assets & 24 \\
\hline & Business Coordinated Development & Professional evaluation methods & 100 \\
\hline & non-performing loan ratio & Non-performing balance/total assets & 120 \\
\hline $\begin{array}{l}\text { Risk and control } \\
\text { class }\end{array}$ & $\begin{array}{l}\text { Pay close attention to loan migration } \\
\text { rate }\end{array}$ & Newly increased NPL/ loan balance & 80 \\
\hline & Internal Control & $\begin{array}{l}\text { Detailed rules for the implementation of internal control, } \\
\text { law and science and technology }\end{array}$ & -120 \\
\hline
\end{tabular}

The president's responsibility system plays a dominant role in the performance appraisal of the bank. The following is the distribution of the performance appraisal of the bank: The president's responsibility system sets four departments, including planning and accounting department, business units, human resources department, internal control compliance department [3]. Planning and accounting department is responsible for the formulation or annual revision of performance appraisal methods. Then, the office of the president will be effective after being issued by the Ministry of Finance and planning. Business units department is responsible for the provision and review of basic data. Human resources department is responsible for the distribution of benefits wages and other resources. Internal control compliance department is responsible for auditing compliance and data authenticity of each bank.
The specific process of performance appraisal in the bank is as follows: The relevant departments review original data (except electronic documents) in 5 days after the season or 7 days after the year [4]. Then, send the data to the planning and accounting department. The paper copy signed and stamped with the department chief chapter. Evaluation results are approved by the president after being reviewed by president's office in 10 days after the season or 15 days after the year.

The assessment results are composed of assessment score and performance level. Table 1 shows clearly the different performance grades assigned by the bank to the sub branches of different assessment scores.

Table 2: Grade distribution table of branch performance evaluation

\begin{tabular}{|l|l|}
\hline Performance rating & Examination score \\
\hline Excellent A+ & $(90,100]$ \\
\hline Good A & $(80,90]$ \\
\hline Competent B & $(70,80]$ \\
\hline General C & $(60,70]$ \\
\hline Poor D & $\leq 60$ \\
\hline
\end{tabular}

The higher assessment score, the higher the level of performance. The evaluation results are the main basis to evaluate the management level of each branch bank, senior management capability and operation results [5]. The performance appraisal system is investigated by the quarterly performance to evaluate, reward and punish every bank and conduct annual liquidation and summary. Concrete implementation mode is to distribute on the basis of monthly performance, reward and punish on the basis of per season performance and sum at the end of the year. Above all, the bank should allocate employee's performance salary properly.

\subsection{The current situation of employee motivation mechanism} in bank

The incentive mechanism of commercial bank to employees mainly is realized by salary, which is composed of basic salary, performance salary and benefits. In recent years, the bank's compensation incentive system is constantly improved. The bank represents many third-party products, such as agency service and insurance business, which promotes reform of the salary incentive system of bank. 
Table 3 is a summary of the salary of ordinary employees.

Table 3: Salary classification table

\begin{tabular}{|l|l|l|l|}
\hline Salary composition & $\begin{array}{l}\text { The proportion of } \\
\text { total compensation }\end{array}$ & stability & characteristic \\
\hline Basic pay & $55 \%$ & good & $\begin{array}{l}\text { It is the basic demand guarantee of employees, but } \\
\text { too high basic salary will reduce the enthusiasm of } \\
\text { employees }\end{array}$ \\
\hline Merit Pay & $35 \%$ & difference & $\begin{array}{l}\text { Can effectively improve the working enthusiasm of } \\
\text { the staff, but may cause short-term behavior of the } \\
\text { pursuit of the interests of employees }\end{array}$ \\
\hline fringe benefit & $10 \%$ & good & Improve employee satisfaction to service \\
\hline
\end{tabular}

Too low basic salary makes the employees' needs not to be met, which results in employee turnover and increases staff instability. But too high basic pay can make workers comfortable and make them have no sense of urgency to the current position which is not conducive to the improvement of bank employees' self-improvement and not conducive to the long-term development of banks.

Performance awards are too low, which will lead to the low enthusiasm of the staff, low initiative and low competition between employees. It finally results in lower overall performance level. However, performance awards are too high, which will make employees try to achieve their profit-driven goals by extreme means. It will increase instability of banks.

We can find the bank's salary consists of three parts from figure 2 , which is reasonable. However, the internal salary differences is not big in the bank, which will lead to the phenomenon of the average of internal salary system.

\subsection{Current situation of cashier performance evaluation system}

Tellers are accounted for the highest number of employees in the bank. The business volume of the teller is composed of the number of business, the amount of deposit marketing and the amount of electronic bank marketing [6]. Their business volume work is higher compared with other staff and there is fierce competition among employees. The performance assessment includes quantitative assessment indicator and qualitative assessment indicator in the bank. Specific indicators include business volume, business quality, business knowledge, business skills, work ability, service quality and work attitude.

\section{PROBLEMS EXISTING IN THE PERFORMANCE EVALUATION SYSTEM OF SIHONG COMMERCIAL BANK}

\subsection{The performance appraisal of the subordinate branch is} unreasonable

DISTRIBUTION OF PERFORMANCE BONUS SCHEME

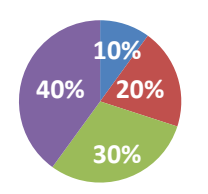

$$
\begin{aligned}
& \text {-60--70分 } \\
& \text {-70--80分 } \\
& \text {-80--90分 }
\end{aligned}
$$

Figure 1: Distribution of performance bonus scheme

From the picture above, the bank has some problems with its branches in the distribution of performance rewards and punishments. Although the score and salary of performance assessment are positively correlated, it is not linearly positive. So there must be some flaws in this distribution system. For example, if the managers got more than sixty points in the assessment of a semester or yearly performance, They may take some unjustifiable methods to promote their performances for more salary. The accounting system has certain flexibility, and the performance appraisal depends mainly on the indexes of profits, so they could imply some seemingly reasonable ways to improve the company profits. Such as incomes confirmed early, expenses confirmed delayed, etc. When the performance evaluation score is less than sixty points, they still use the measures to promote the current period profits to meet the appraisal performance requirements. From the picture, we can see that the differences in bonuses between eighty points and ninety points is not distinct, so the managers will use these measures to ensure that the number whose scores are more than 80 points is not much.

Another situation is that agricultural and commercial Banks will combine with the former performance to predict its expected performance. Then the managers and employees deliberately keep their current performances at a relatively low level, this inevitably causes the former performances are not outstanding, so the next performance appraisal standard would not have obvious improvement. The branch bank will not take the risks of lower performance appraisal in the future. By the ways, the banks reduce its real profits, lowered its expected performance, and control the performance appraisal scores around 80 points to obtain the biggest salaries, this is the so-called "ratchet effect".

Generally speaking, the performance appraisal system has its obvious shortcomings. It may trigger a lot of branch banks purse Short-term interest behaviors. For example, employees would take some harmful measures to get a higher evaluation result. Moreover, it will harm the longterm development of the enterprise. The non-linear performance appraisal and punishment system has the shortcomings of with reward and without punishment. For example, the head and staff of the branch who got under 60 points in the evaluation may still receive the full salary and related benefits. It could cause some managers save this semester surplus to next semester in order to get greater rewards and compensations.

\subsection{Problems existing in the incentive mechanism of employees}

The rural commercial bank sets up different jobs, and the salaries vary in different positions. However, when the position is the same, no matter the work you need to do whether has been completed, the salary is the same. This situation inevitably leads to average salary of the same position. And the number of employees in rural commercial banks is more than other commercial banks, the salary management is difficult to implement because of its complicated structure, even when it has been used in practice, the cost of it is too high to be underestimated, so the current salary system of the rural commercial bank does not make excessive adjustment based on tradition. The staff of the rural commercial bank are mainly divided into cabinet operators, customer managers, executives and managers, and the salary of them is based on this classification, but there is not a perfect incentive system for technical workers, this will damage the enthusiasm of excellent employees. Two drawbacks have been found because of its defective salary system and overstaffing.

On the one hand, the phenomenon of average salary has produced. In particular, the salary of internal staff of bank branches are same, but there is a big difference in the accomplishment of their work. For example, in May 14, Li, the lobby manager of the bank, handled 281 business cases, and another lobby manager, Liu, handled 56 business days, and the salary of LI is only 200 YUAN more than LIU. This kind of salary system looks fair. However, because of this fair, the LI's zeal for work will not higher than 
before. If the salary system is not changed, more and more employees will lose the enthusiasm of work so that the efficiency of their work will be a sharp decline. And the decline of work accomplishment will ultimately have a negative impact on the long-term development of the bank.

On the other hand, special third-party products launched the bank will bring additional benefits for employees. For example, insurance companies provide insurance business to banks, when the employees of bank promote them to customers, they will get a considerable rebates. Sometimes these rebates will go far beyond their monthly salary. This unreasonable pay system will inevitably lead to extreme profit seeking behavior, which also frustrating the enthusiasm of other excellent employees at the same time.

\subsection{The problem of the performance evaluation of the teller}

The evaluation index is single, and the evaluation result has limitations. Such as the bank of the performance evaluation of personal financial advisor positions most converged on the financial product sales, and it less converged on the customer satisfaction, customer churn rate and so on examination of enterprise future growth index. It still pays attention to the performance evaluation of financial indicators, despise the non-financial indicators, but there are some indicators to the commercial Banks of transition phase, which plays a crucial role, such as customer value, staff growth indicator.

Excessive pursuit of financial indicators will have many disadvantages: Firstly, it leads to the pursuit of short-term goal behavior, which is not conducive to the rapid development of Banks. Secondly, financial indicators are mainly measured by past operating results, which cannot reflect the strong and weak change of enterprise strength. Thirdly, the bank's financial index system is mainly based on past performance evaluation, which is impossible for companies to get long-term development.

\section{THE COUNTERMEASURES AND SUGGESTIONS FOR IMPROVING THE PERFORMANCE EVALUATION SYSTEM OF AGRICULTURAL AND COMMERCIAL BANKS}

\subsection{Introduce the EVA concept into the performance evaluation system}

\subsubsection{Introduce EVA core ideas}

In view of the above-mentioned problems, I think we can improve it by introducing EVA management concept. The traditional accounting evaluation index only depends on the company's external debt interest, while ignoring the capital cost of the shareholders. As a new core idea, EVA calculates the value of enterprise profits more accurately by taking into account the cost of debt interest and the capital cost of shareholders.

\subsubsection{EVA index calculation}

The traditional EVA calculation formula is expressed as: EVA=NOPAT Capital appropriation*WACC rate.

However, since the banking industry has its specificity, the EVA of commercial bank is different from the traditional EVA calculation in the way of measurement capital occupation. Therefore, the calculation formula of EVA of commercial bank is expressed as: EVA=NOPAT TC*WACC

\section{$\Phi$ Calculation of NOPAT}

NOPAT is based on the basis of net profit after adjusting the post-tax aftertax operating income and all kinds of expenses.

NOPAT $=[$ net profit + allowance for decrease of assets $+(-)$ non-operating expenditure(revenue) - change of deferred tax assets + change of deferred tax liabilities] ${ }^{*}(1-\mathrm{Tr})$

Table 4: NOPAT computation sheet of a bank in 2013-_2015 unit: million

\begin{tabular}{|c|c|c|c|}
\hline account period & $\mathbf{2 0 1 3}$ & $\mathbf{2 0 1 4}$ & $\mathbf{2 0 1 5}$ \\
\hline net profit & 212519.00 & 225454.00 & 225176.00 \\
\hline allowance for decrease of assets & 23463.00 & 18951.00 & -1900.00 \\
\hline non-operating revenue & 2583.00 & 2943.00 & 3705.00 \\
\hline non-operating expenditure & 890.00 & 1172.00 & 1335.00 \\
\hline net income after tax & 1269.75 & 1328.25 & 1777.50 \\
\hline change of deferred tax assets & 11576.00 & -978.00 & -13817.00 \\
\hline change of deferred tax liabilities & 38.00 & 43.00 & 0.00 \\
\hline NOPAT & 221904.50 & 242769.50 & 233538.00 \\
\hline
\end{tabular}

8 The calculation of total capital

$\mathrm{TC}=$ stockholders'equity + balance of decrease of assets +(-) aggregation of non-operating expenditure(revenue) - balance of deferred tax assets + balance of deferred tax liabilities

Table 5: TC computation sheet of a bank in 2013-_2015 unit: million

\begin{tabular}{|c|c|c|c|}
\hline account period & $\mathbf{2 0 1 3}$ & $\mathbf{2 0 1 4}$ & $\mathbf{2 0 1 5}$ \\
\hline stockholders'equity & 1058601.00 & 1251848.00 & 1445083.00 \\
\hline balance of decrease of assets & 241800.00 & 260751.00 & 258851.00 \\
\hline aggregation of net income & 1693.00 & 1771.00 & 2370.00 \\
\hline aggregation of net income after tax & 1269.75 & 1328.25 & 24298.00 \\
\hline balance of deferred tax assets & 39093.00 & 38115.00 & 81.00 \\
\hline balance of deferred tax liabilities & 0.00 & 43.00 & 1679124.50 \\
\hline TC & 1260884.75 & 1474084.25 & \\
\hline
\end{tabular}

3 The calculation of WACC

Equity capital is the main component of capital total, so the calculation of WACC needs only to consider the cost of equity capital. WACC $=$ risk-free rate $+\beta^{*}$ (market profitability - risk-free rate $)$ 
Table 6: $\beta$ distribution table of a bank in 2013--2015

\begin{tabular}{|c|c|c|c|}
\hline account period & $\mathbf{2 0 1 3}$ & $\mathbf{2 0 1 4}$ & $\mathbf{2 0 1 5}$ \\
\hline$\beta$ & 0.582 & 0.459 & 0.671 \\
\hline
\end{tabular}

Table 7: Risk-free rate distribution table of a bank in 2013-—2015

\begin{tabular}{|c|c|c|c|}
\hline account period & $\mathbf{2 0 1 3}$ & $\mathbf{2 0 1 4}$ & $\mathbf{2 0 1 5}$ \\
\hline $\mathrm{Rf}$ & $3.61 \%$ & $3.42 \%$ & $3.45 \%$ \\
\hline
\end{tabular}

Table 8: Market risk premium distribution table of a bank in 2013-—2015

\begin{tabular}{|c|c|c|c|}
\hline account period & $\mathbf{2 0 1 3}$ & $\mathbf{2 0 1 4}$ & $\mathbf{2 0 1 5}$ \\
\hline $\mathrm{Rm}-\mathrm{Rf}$ & $7.70 \%$ & $7.21 \%$ & $7.15 \%$ \\
\hline
\end{tabular}

Table 9: WACC computation sheet of a bank in 2013-_2015

\begin{tabular}{|c|c|c|c|}
\hline account period & $\mathbf{2 0 1 3}$ & $\mathbf{2 0 1 4}$ & $\mathbf{2 0 1 5}$ \\
\hline$\beta$ & 0.582 & 0.459 & 0.671 \\
\hline Rf & $3.61 \%$ & $3.42 \%$ & $3.45 \%$ \\
\hline Rm-Rf & $7.70 \%$ & $7.21 \%$ & $7.15 \%$ \\
\hline WACC & $8.0914 \%$ & $6.7294 \%$ & $8.2477 \%$ \\
\hline
\end{tabular}

$\$$ The calculation of EVA

EVA=NOPAT - TC*WACC

Table 10: EVA computation sheet of a bank in 2013-—2015 unit: million

\begin{tabular}{|c|c|c|c|}
\hline account period & $\mathbf{2 0 1 3}$ & $\mathbf{2 0 1 4}$ & $\mathbf{2 0 1 5}$ \\
\hline NOPAT & 221904.5 & 1474084.25 & 233538 \\
\hline TC & 1260884.75 & $6.73 \%$ & 1679124.5 \\
\hline WACC & $8.09 \%$ & 143572.4745 & $9.25 \%$ \\
\hline EVA & 119881.2713 & & 95048.84861 \\
\hline
\end{tabular}

The above calculation principle is the standard of the performance appraisal of the agricultural and commercial bank.

In order to realize the transformation from the traditional scale to the modern value orientation, it is necessary to introduce the EVA index in the performance appraisal. Thus, it can also pursue the maximization of value and value creation under the premise of proper scale expansion. This will not only satisfy the return on equity capital and capital constraints, but also accelerate the trend of bank profitability diversification and interest rate liberalization of Banks.

\subsubsection{Based on EVA to build performance rewards and punishment scheme}

We need to construct an EVA based performance reward and punishment system to solve the above problems. EVA performance rewards and punishments can be expressed as follows:

total bonus=target bonus $+\mathrm{S} \%$ (practical EVA-predicted EVA)

S\% expresses that the excess EVA accounts for the proportion of the total bonus.

There are three advantages to adopting this model. Firstly, the incentive effect of this model is more humane.Second, the EVA increment represents economic value added, which is also very useful for Banks. Finally, in terms of EVA increment, there is a direct link between the model and the excess return, which can drive the initiative of the organization and employees.Above all EVA can relatively accurately reflect the actual performance of completion as well as the value-added of the branches, so EVA performance rewards and punishment scheme is more suitable for all branches and departments, through the EVA performance rewards and punishment model with the branches and departments are tied to executive bonuses, to make the bank management incentive more longterm, avoid the happening of executives to pursue short-term interests behavior.

\subsection{Establish a scientific and reasonable employee incentive system}

Based on the shortcomings of the bank's assessment of employees, this paper will focus on the analysis from the perspective of counter operators. The counter operator is the main force of the traditional business and the new development agency, who has the most business. Competition is fiercest in the industry, and it is the largest proportion in the bank staff, but their salary is the lowest in the industry. In daily operation, the teller is also the most neglected group, but they are vital to the development of the bank, and their attitude towards work will directly affect the benefit of the bank. Therefore, the bank should focus on setting a reasonable compensation system for the tellers to stimulate their enthusiasm. 
Topics in Economics, Business and Management (EBM) 2(2) (2018) 01-06

Figure 11: Indicator system of teller performance evaluation

\begin{tabular}{|c|c|c|c|c|}
\hline $\begin{array}{ll}\text { Dimension } & \text { and } \\
\text { weight }\end{array}$ & Strategic objectives & Action plan & KPI & Weight \\
\hline \multirow[t]{2}{*}{$\begin{array}{l}\text { Financial perspective } \\
20 \%\end{array}$} & \multirow[t]{2}{*}{$\begin{array}{ll}\text { Trading } & \text { income } \\
\text { stability } & \end{array}$} & $\begin{array}{l}\text { Conduct accounting } \text { transactions } \\
\text { according to internal banking } \\
\text { regulations }\end{array}$ & \multirow[t]{2}{*}{$\begin{array}{l}\text { Transaction error } \\
\text { rate }\end{array}$} & \multirow[t]{2}{*}{$20 \%$} \\
\hline & & Avoid mistakes in trading & & \\
\hline \multirow[t]{4}{*}{$\begin{array}{l}\text { Customer dimension } \\
35 \%\end{array}$} & \multirow[t]{2}{*}{$\begin{array}{l}\text { Maintain existing VIP } \\
\text { customer } \\
\text { relationship }\end{array}$} & Offer good services & $\begin{array}{l}\text { Customer } \\
\text { satisfaction }\end{array}$ & $9 \%$ \\
\hline & & $\begin{array}{lll}\text { Establish long-term } & \text { customer } \\
\text { relationship } & & \\
\end{array}$ & $\begin{array}{l}\text { Customer churn } \\
\text { rate }\end{array}$ & $9 \%$ \\
\hline & \multirow{2}{*}{$\begin{array}{lr}\text { Expand } & \text { high-end } \\
\text { customers } & \text { and } \\
\text { expand } & \text { market } \\
\text { impact } & \end{array}$} & $\begin{array}{l}\text { Submit customer } \\
\text { complaints and Suggestions to the } \\
\text { customer manager in time }\end{array}$ & $\begin{array}{l}\text { Customer } \\
\text { complaints }\end{array}$ & $9 \%$ \\
\hline & & enhance propaganda & $\begin{array}{l}\text { High-end } \\
\text { customer } \\
\text { recommendation }\end{array}$ & $8 \%$ \\
\hline \multirow{3}{*}{$\begin{array}{ll}\text { Internal } & \text { process } \\
\text { perspective } & \\
35 \% & \end{array}$} & compliance & \multirow{3}{*}{$\begin{array}{l}\text { Strengthen the learning and } \\
\text { popularization of bank-related } \\
\text { regulations to improve the hourly } \\
\text { rate, fully understand the system } \\
\text { operation manual and implement it } \\
\text { carefully }\end{array}$} & $\begin{array}{l}\text { Illegal operation } \\
\text { rate }\end{array}$ & $13 \%$ \\
\hline & $\begin{array}{l}\text { improve } \\
\text { efficiency }\end{array}$ & & $\begin{array}{ll}\begin{array}{l}\text { Hourly } \\
\text { efficiency }\end{array} & \text { work } \\
\end{array}$ & $10 \%$ \\
\hline & $\begin{array}{l}\text { The system } \\
\text { information is } \\
\text { accurate and correct }\end{array}$ & & $\begin{array}{l}\text { Operating error } \\
\text { rate }\end{array}$ & $12 \%$ \\
\hline \multirow{2}{*}{$\begin{array}{l}\text { Learning and growth } \\
\text { perspective } \\
10 \%\end{array}$} & \multirow{2}{*}{$\begin{array}{l}\text { Fully understand the } \\
\text { bank operation } \\
\text { knowledge, improve } \\
\text { the qualification }\end{array}$} & \multirow{2}{*}{$\begin{array}{l}\text { Conduct regular operation process } \\
\text { training on branch branches and } \\
\text { obtain necessary qualification } \\
\text { certificates }\end{array}$} & Training hours & $6 \%$ \\
\hline & & & $\begin{array}{l}\text { The number of } \\
\text { necessary } \\
\text { qualification }\end{array}$ & $4 \%$ \\
\hline
\end{tabular}

Table 11 is a strategy-oriented performance evaluation index system based on the actual situation of the bank. This paper considers that salary should be made up of four parts, including basic wage, performance salary, the year-end bonus and other benefits. The proportion of each dimension listed in the above table should be considered in proportion to the salary of the teller. It will be more scientific and reasonable to the compensation incentive mechanism of teller.

\section{REFERENCES}

[1] Hoque, Z. 2014. 20 years of studies on the balanced scorecard: Trends, accomplishments, gaps and opportunities for future research Original Research Article. The British Accounting Review, 46 (1).

[2] El-Hindawy, M.A.M., Alamasi, A.M.S. 2014. Measurement of the Strategic Performance of Hospitality in the Kingdom of Saudi Arabia: a balanced scorecard Approach (BSC). Original Research Article Arab Economic and Business Journal, 9 (1).

[3] Gonzalez, J.M.H., Calderon, M.A., Gonzalez, J.L.G. 2012. The alignment of managers' mental models with the balanced scorecard strategy map [J]. Total Quality Management \&amp; Business Excellence.

[4] Amado, C.A., Santos, S.P., Marques, P.M. 2012. Integrating the Data Envelopment Analysis and the Balanced Scorecard approaches for enhanced performance assessment [J].Omega.

[5] Sternm, Willett, T.A. 2014. Bock back at the beginnings of EVA and value-based management [J]. Journal of Applied Corporate Finance, 26 (1), 39- 46.

[6] Baranchuk, N., Kieschnick, R., Moussawi, R. 2014. Motivating innovation in newly public firms [J]. Journal of Financial Economics,111 (3), 578-588. 